\title{
Effect of Conjugation Length on Intrachain Chromophore-Chromophore Interaction in Silylene-Spaced Divinyloligoarene Copolymers
}

\author{
Yen-Ju Cheng, ${ }^{\dagger}$ Sourav Basu, ${ }^{\dagger}$ Shr-Jie Luo, ${ }^{\dagger, \S}$ and Tien-Yau Luh ${ }^{*, \dagger, \ddagger}$ \\ Department of Chemistry and Institute of Polymer Science and Engineering, National Taiwan \\ University, Taipei, Taiwan 106, and Institute of Chemistry, Academia Sinica, Taipei, Taiwan 106 \\ Received November 8, 2004; Revised Manuscript Received December 1, 2004
}

\begin{abstract}
A range of silylene-spaced divinyloligoarene alternating copolymer $\mathbf{3}$ has been synthesized regioregularly by rhodium-catalyzed hydrosilylation of bis(alkynes) $\mathbf{5}$ with bis(silanes) 6. Monomeric reference compounds $\mathbf{4}$ having similar chromophore components were also prepared for comparison. The silylene moieties serve as insulating spacers between chromophores. Intrachain interaction appears to be negligible due to the localization of exciton in these conjugated chromophores, resulting in the emission that closely resembles that of the parent chromophore.
\end{abstract}

\section{Introduction}

Well designed interruption of $\pi$-conjugation along the polymer backbone by insulating spacers allows tuning of the photophysical properties of the polymers and furnishes processable materials. ${ }^{1-5}$ There has been an increasing study of using silylene moiety as the spacer..$^{2-5}$ In general, when the silylene spacer contains only one silicon atom, no conjugative interactions between the $\pi$ systems and the silicon moiety is observed. We recently reported a series of silylene-spaced divinylarene copolymers that exhibit versatile photophysical properties such as intrachain energy transfer, ${ }^{6}$ through space chromophore-chromophore interactions, ${ }^{7}$ and the transmission of chiroptical properties. ${ }^{8}$ Theoretical $^{9-11}$ and experimental ${ }^{12}$ studies on inter- or intrachain interactions between chromophores have been extensive. Model compounds such as paracyclophanes and polystilbene derivatives provide useful insight for understanding interchromophore delocalization through space. ${ }^{12}$ The extent of such through-space interactions in the excited state has been suggested to be dependent on the conjugation length of chromophores. The shorter the conjugation length, the more is prone to delocalization over interacting chromophores leading to excimer formation. On the contrary, as the conjugation length increases, the interactions between chromophores may be significantly reduced because the geometry relaxation in the excited state of longer conjugated moieties may stabilize the localization of exciton in a single chromophore. Indeed, the aforementioned silylene-spaced divinylbenzene copoymers 1 have been shown to exhibit molecular-weight dependent aggregate emission profiles which suggest that significant intrachain chromophorechromophore interactions may occur. ${ }^{7,13}$ In our preliminary communication, we found that the emission spectrum of copolymer $\mathbf{2}$ is very similar to that of the corresponding monomer. ${ }^{7}$ The divinylterthiophene moiety has longer conjugation length than divinylbenzene chromophore so that exciton may be able to localize in this chromophore. In this paper, we report a systematic

\footnotetext{
$\dagger$ Department of Chemistry, National Taiwan University.

$\pitchfork$ Institute of Polymer Science and Engineering, National Taiwan University.

$\S$ Institute of Chemistry, Academia Sinica.
}

investigation on the effect of conjugation length of chromophore in a series of silylene-spaced regioregular divinyloligoarene copolymers $\mathbf{3}$.

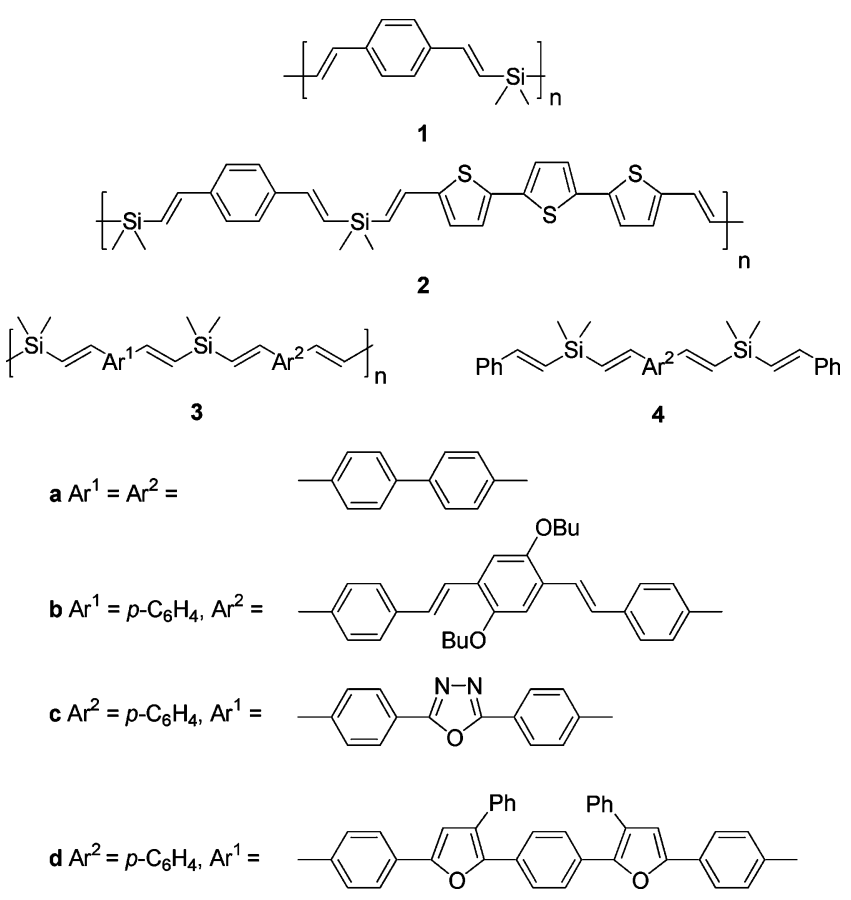

\section{Results and Discussion}

Synthesis. The divinyloligoarene chromophores of different conjugation lengths and structural variety were incorporated into the corresponding copolymers $\mathbf{3 a}-\mathbf{d}$. Copolymers $\mathbf{3 a}-\mathbf{d}$ were synthesized by the hydrosilylation of bis(alkynes) $\mathbf{5}$ with the corresponding bis(silane) 6 in a manner similar to those described previously (eq 1). ${ }^{5}$ The corresponding monomeric model compounds $4 \mathbf{a}-\mathbf{d}$ were prepared similarly by either hydrosilylation of bis(silanes) 6 with phenylacetylene (7) or bis(alkynes) 5 with 2-(phenyl)vinyldimethylsilane (8) (eqs 2 and 3). ${ }^{7}$ The preparation of furan-containing pentaaryls 4d was based on the one-pot furan synthesis recently developed in our laboratory. ${ }^{14}$ Thus, treatment of propargylic dithioacetal 9 with $n$-BuLi followed by terephthaldicarboxaldehyde to give the intermediate 


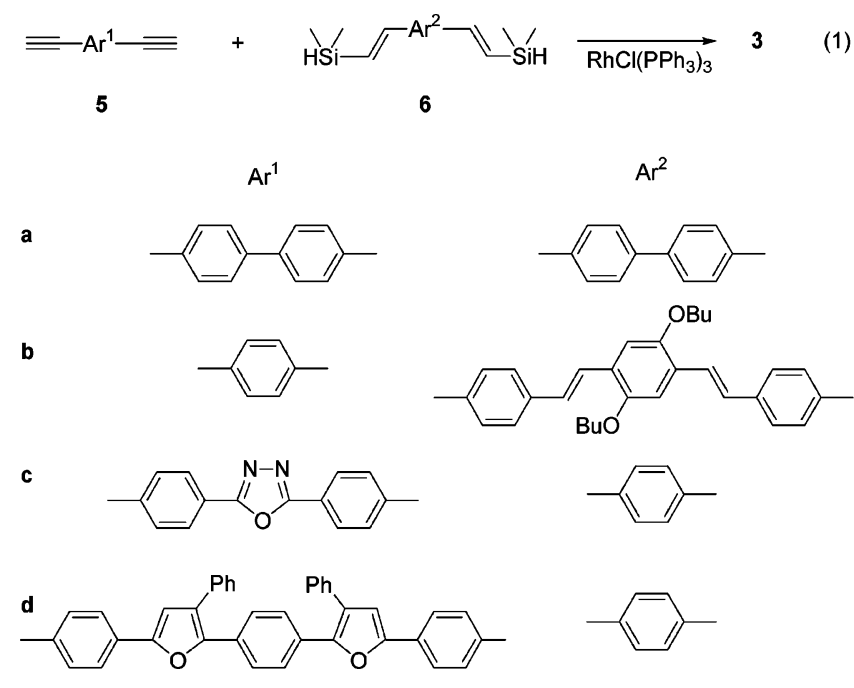

which underwent cyclization under acidic condition to yield furan-containing pentaaryl 10 in $55 \%$ yield. Deprotection of the TMS group in $\mathbf{1 0}$ afforded $\mathbf{5 d}$ in $\mathbf{9 2 \%}$ yield (eq 4). The details are summarized in the Experimental Section.

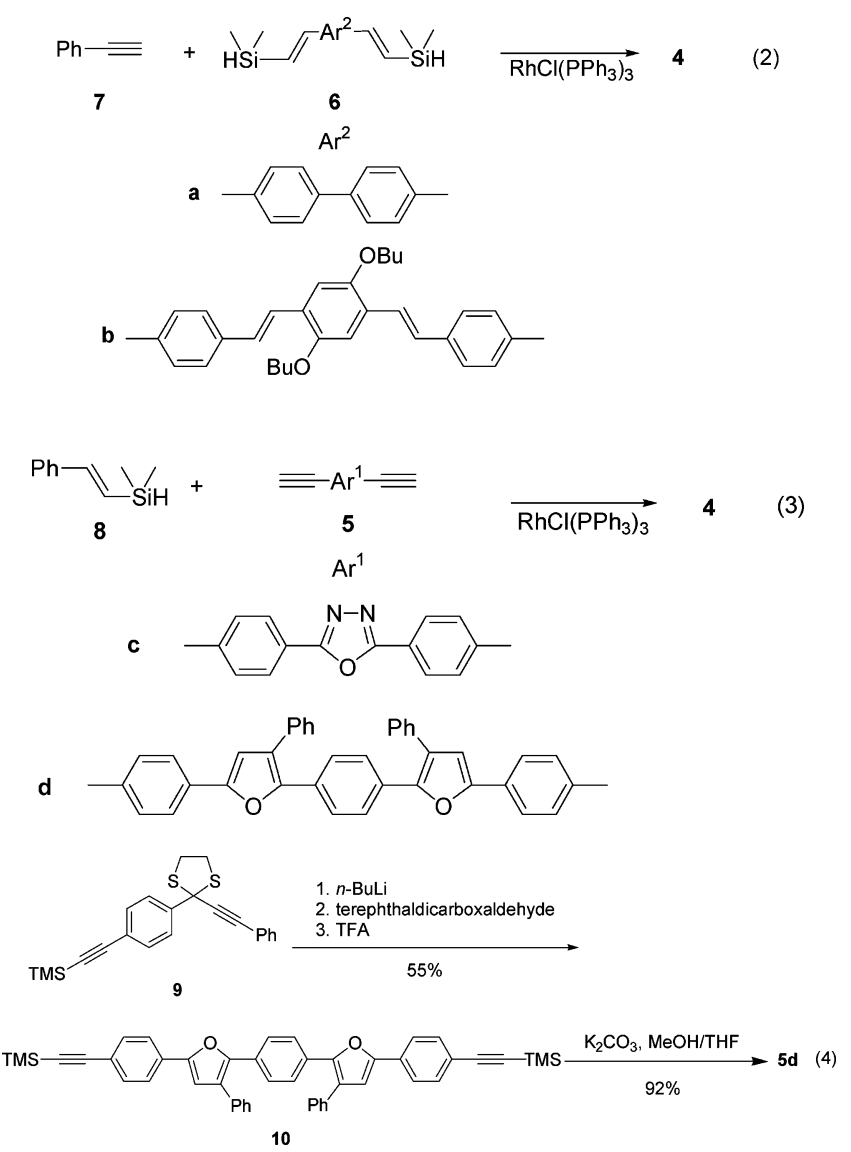

\section{Photophysical Properties}

The absorption, emission and excitation spectra of copolymers 3a-d are shown in Figures 1-4, and those of the corresponding monomeric compounds $4 \mathbf{a}-\mathbf{d}$ are compared in the respective figures. The $\lambda_{\max }$ of the chromophores were chosen as the corresponding excitation wavelengths in emission spectra for each of these copolymers. It is noteworthy that the aromatic moieties in polymers $\mathbf{3 b}-\mathbf{d}$ have relatively long conjugation length in comparison with that in 1. Figures

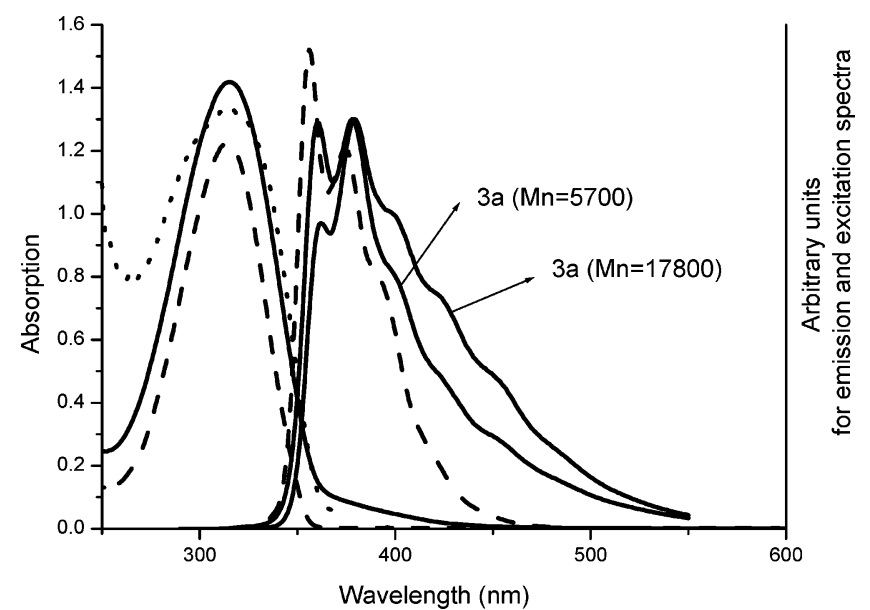

Figure 1. Absorption spectra of $\mathbf{3 a}$ (solid line) and $\mathbf{4 a}$ (dashed line), excitation spectrum of $\mathbf{3 a}$ (dotted line, $\left.\lambda_{\mathrm{em}}=370 \mathrm{~nm}\right)$ in $\mathrm{CHCl}_{3}$, and emission spectra of $\mathbf{3 a}\left(M_{\mathrm{n}}=5700\right.$ and 17800 , solid line) and $\mathbf{4 a}$ (dashed line, $\left.\lambda_{\mathrm{ex}}=310 \mathrm{~nm}\right)$ in $\mathrm{CHCl}_{3}$.

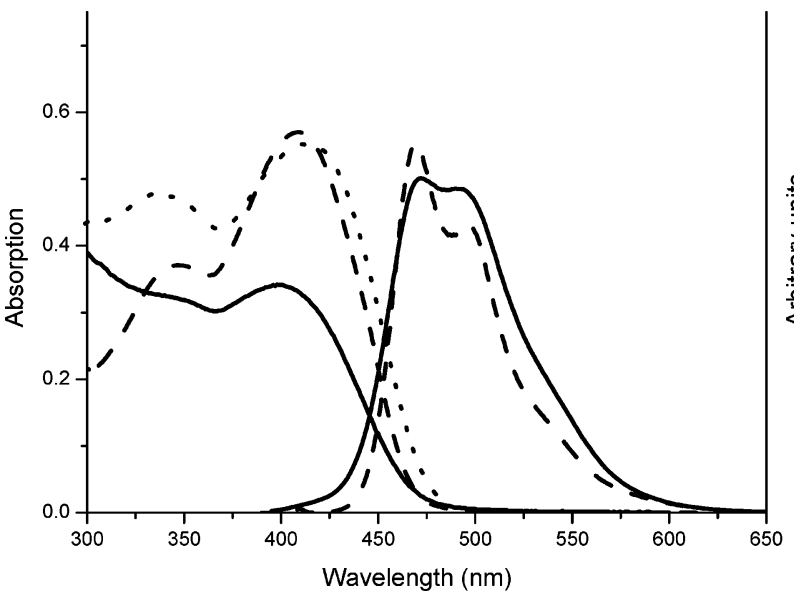

Figure 2. Absorption spectra of $\mathbf{3 b}$ (solid line) and $\mathbf{4 b}$ (dashed line) and excitation spectrum of $\mathbf{3 b}$ (dotted line, $\left.\lambda_{\mathrm{em}}=490 \mathrm{~nm}\right)$ in $\mathrm{CHCl}_{3}$ and emission spectra of $\mathbf{3 b}$ (solid line) and $\mathbf{4 b}$ (dashed line, $\lambda_{\mathrm{ex}}=410 \mathrm{~nm}$ ) in $\mathrm{CHCl}_{3}$.

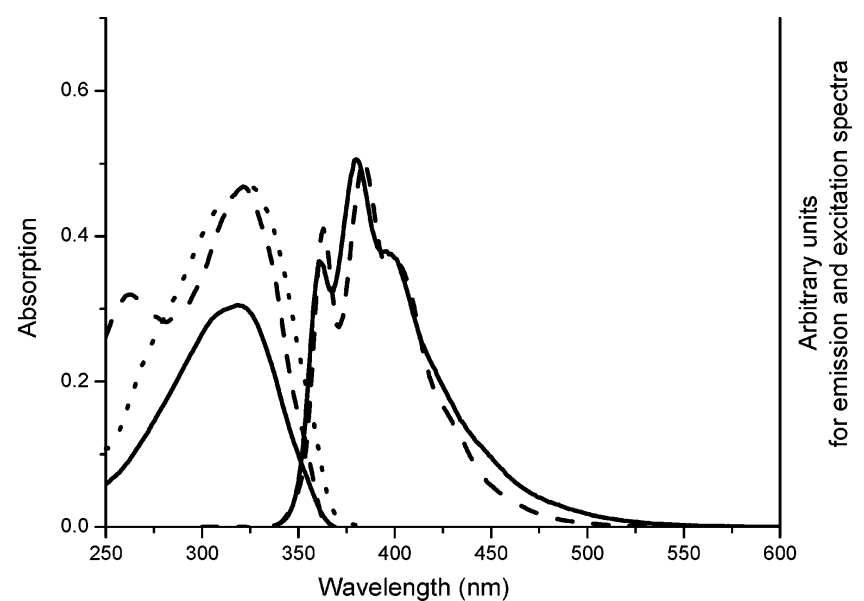

Figure 3. Absorption spectra of 3c (solid line) and 4c (dashed line) and excitation spectrum of $3 \mathbf{c}$ (dotted line, $\left.\lambda_{\mathrm{em}}=390 \mathrm{~nm}\right)$ in $\mathrm{CHCl}_{3}$ and emission spectra of $3 \mathbf{c}$ (solid line) and $4 \mathbf{c}$ (dashed line, $\lambda_{\mathrm{ex}}=324 \mathrm{~nm}$ ) in $\mathrm{CHCl}_{3}$.

2-4 show the spectroscopic properties of three representative examples, polymer $\mathbf{3 b}$ having terphenylenetetravinylene chromophore, polymer 3c containing divinyldiphenyloxadiazole chromophore, and polymer 3d containing divinylpentaaryl chromophore. The excita- 


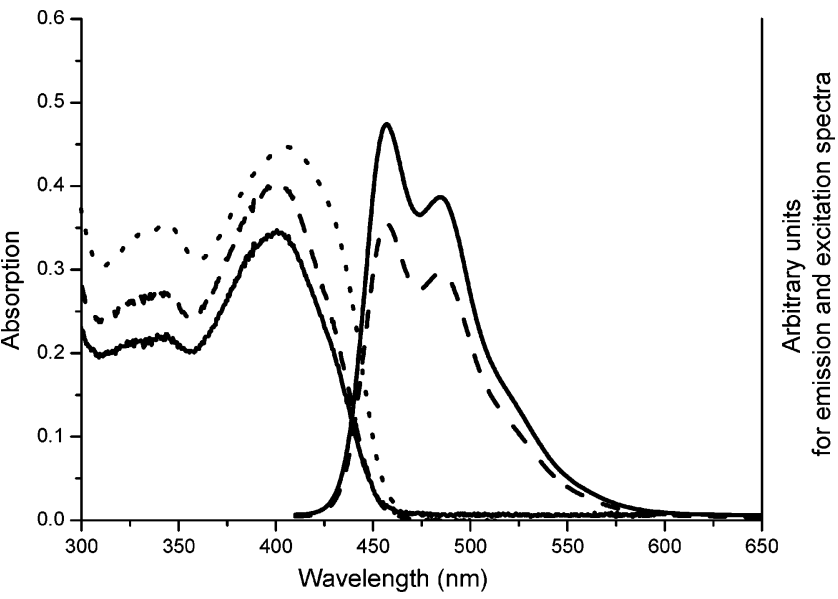

Figure 4. Absorption spectra of 3d (solid line) and 4d (dashed line) and excitation spectrum of $\mathbf{3 d}$ (dotted line, $\lambda_{\mathrm{em}}=485 \mathrm{~nm}$ ) in $\mathrm{CHCl}_{3}$ and emission spectrum of 3d (solid line) and $\mathbf{4 d}$ (dashed line, $\lambda_{\mathrm{ex}}=400 \mathrm{~nm}$ ) in $\mathrm{CHCl}_{3}$.

tion and absorption spectra of polymers $\mathbf{3 b}-\mathbf{d}$ are very similar to those of corresponding monomers $4 \mathbf{b}-\mathbf{d}$, respectively. In addition, the emission profiles for polymers $\mathbf{3 b}-\mathbf{d}$ are essentially the same as those for the corresponding monomers $\mathbf{4} \mathbf{b}-\mathbf{d}$ having the same divinyloligoarene chromophores. The silicon moiety in these polymers may serve as an insulating spacer.

These results suggested that the photophysical properties of $\mathbf{3 b}-\mathbf{d}$ are very different from those of $\mathbf{1}$ or related silylene-spaced mononuclear divinylarene copolymers. ${ }^{7 \mathrm{a}}$ It is thus believed that intrachain throughspace interaction between chromophores in these polymers due to folding of the polymeric chain may not take place leading to the excimer formation.

As shown in Figure 1, besides the absorption at the corresponding $\lambda_{\max }$, there was a tailing absorption extended to the longer wavelength for copolymers $\mathbf{3 a}$ having divinylbiphenyl chromophores. Similar to those of divinylbenzene copolymers 1,7 the emission at longer wavelengths may arise from the through-space intrachain interaction between chromophores owing to the folding aggregate. ${ }^{13}$ The relative intensity for the longer wavelength emission in 3a, however, is slightly affected by increasing the degree of polymerization. Vibronic fine splittings were vaguely found in these fluorescence spectra. The intrachain $\pi-\pi$ interaction between divinylbiphenyl moieties in $\mathbf{3 a}$ might, therefore, be less favorable than those of divinylbenzene analogues $\mathbf{1}$ because of its longer conjugation length. These results are consistent with the models on the interactions of conjugated systems. ${ }^{12}$

\section{Conclusions}

In summary, we have systematically investigated the influence of conjugation length of chromophores on the photophysical behavior of silylene-spaced divinylarene copolymers 3. When the chromophores in silylenespaced copolymer are mononuclear divinylarenes, through-space delocalized interchromophoric contact prevails, leading to emission at longer wavelengths due to intrachain aggregation. ${ }^{7 a}$ When the conjugation length of chromophore increases, the intrachain interaction appears to be negligible due to the localization of exciton in these longer conjugated chromophores, resulting in the emission that closely resembles that of the parent chromophore. Our results suggest that the silylene moieties simply serve as insulating spacer, no conjugation with the $\pi$-system being observed. ${ }^{3 \mathrm{f}}$

\section{Experimental Section}

Compounds $4 \mathbf{c}^{6 \mathrm{6a}} 5 \mathbf{c},{ }^{6 \mathrm{aa}} \mathbf{6 b},{ }^{8} \mathbf{6 c}^{7 \mathrm{a}}$ and $\mathbf{8}^{7 \mathrm{a}}$ were prepared according to literature procedures. The absorption spectra were recorded on a Hitachi U-3310 spectrometer. The photoluminescence and excitation spectra were recorded on a Hitachi F-4500 fluorescence spectrometer. Gel permeation chromatography (GPC) was performed on a Waters GPC machine using an isocratic HPLC pump (1515) and a refractive index detector (2414). THF was used as the eluent (flow rate $=1$ mLmin ${ }^{-1}$ ). Waters Styragel HR2, HR3 and HR3 and HR4 (7.8 $\times 300 \mathrm{~mm}$ ) were employed for molecular weight determination. Polystyrene were used as standard $\left(M_{\mathrm{n}}\right.$ values range from 375 to $3.5 \times 10^{6}$ ).

Bis(2-dimethylsilanyl)vinylbiphenyl (6a). A THF solution of $\left.\mathrm{Me}_{2}{ }^{i} \mathrm{PrO}\right) \mathrm{SiCH}_{2} \mathrm{MgCl}$ (10 equiv) was evacuated as much as possible and benzene $(30 \mathrm{~mL})$ was introduced. Under $\mathrm{N}_{2}$, to this mixture was introduced a solution of $4,4^{\prime}-\operatorname{bis}(1,3-$ dithiolan-2-yl)biphenyl (1.45 g, $4.0 \mathrm{mmol})$ and $\mathrm{NiCl}_{2}\left(\mathrm{PPh}_{3}\right)_{2}$ $(0.28 \mathrm{~g}, 0.4 \mathrm{mmol})$ in benzene $(50 \mathrm{~mL})$. The mixture was refluxed under $\mathrm{N}_{2}$ for $16 \mathrm{~h}$ and then poured into saturated $\mathrm{NH}_{4} \mathrm{Cl}$. The organic layer was separated and the aqueous layer was extracted twice $(2 \times 20 \mathrm{~mL})$ with ether. The combined organic portions were washed twice with $10 \% \mathrm{NaOH}(2 \times 20$ $\mathrm{mL})$ and brine $(20 \mathrm{~mL})$ and dried $\left(\mathrm{MgSO}_{4}\right)$. The solvent was removed in vacuo and the residue was triturated with $\mathrm{MeOH}$ to give the solid residue which was mixed with $\mathrm{LiAlH}_{4}(304$ $\mathrm{mg}, 8.0 \mathrm{mmol})$ in benzene $(50 \mathrm{~mL})$. The mixture was refluxed under $\mathrm{N}_{2}$ for $18 \mathrm{~h}$ and then cooled to room temperature, quenched with water, and filtered. The organic layer was separated, dried $\left(\mathrm{MgSO}_{4}\right)$ and the solvent was removed in vacuo to give the residue which was chromatographed on silica gel (hexane) to afford 6a $(0.75 \mathrm{~g}, 58 \%) ; \mathrm{mp} 151-153{ }^{\circ} \mathrm{C}$ (pentane). ${ }^{1} \mathrm{H}$ NMR $\left(200 \mathrm{MHz}, \mathrm{CDCl}_{3}\right): \delta=0.24(\mathrm{~d}, J=3.6$ $\mathrm{Hz}, 12 \mathrm{H}), 4.2(\mathrm{~m}, 2 \mathrm{H}) 6.47\left(\mathrm{dd}, J_{1}=19.2 \mathrm{~Hz}, J_{2}=2.5 \mathrm{~Hz}, 2\right.$ $\mathrm{H}), 6.98(\mathrm{~d}, J=19.2 \mathrm{~Hz}, 2 \mathrm{H}), 7.48(\mathrm{~d}, J=8.0 \mathrm{~Hz}, 4 \mathrm{H}), 7.56$ $(\mathrm{d}, J=8.0 \mathrm{~Hz}, 4 \mathrm{H}) \cdot{ }^{13} \mathrm{C}$ NMR $\left(50 \mathrm{MHz}, \mathrm{CDCl}_{3}\right): \delta=-4.0,126.3$, $126.9,127.0,137.3,140.3,140.8$. IR $(\mathrm{KBr}): v=2966,2906$, $2117,1660,1501,1400,1249,1202,1123,990,888,794,744$,

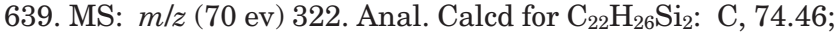
H, 8.12. Found: C, 74.24; H, 8.27.

4,4'-Bis[2-(dimethylstyrylsilanyl)vinyl]biphenyl (4a). A mixture of $\mathbf{6 a}(0.16 \mathrm{~g}, 0.5 \mathrm{mmol})$, phenylacetylene 7 (0.102 $\mathrm{g}, 1 \mathrm{mmol})$, and $\mathrm{RhCl}_{3}\left(\mathrm{PPh}_{3}\right)_{3}(2.3 \mathrm{mg}, 0.5 \mathrm{~mol} \%)$ in THF (5 $\mathrm{mL}$ ) was refluxed for $8 \mathrm{~h}$. Removal of the solvent in vacuo and chromatographic purification on silica gel (pentane) afforded 4a $\left(0.16\right.$ g, 61\%): $\operatorname{mp~} 185-187{ }^{\circ} \mathrm{C}$ (pentane). ${ }^{1} \mathrm{H}$ NMR $(200$ $\left.\mathrm{MHz}, \mathrm{CDCl}_{3}\right): \delta=0.35(\mathrm{~s}, 12 \mathrm{H}), 6.53(\mathrm{~d}, J=19 \mathrm{~Hz}, 2 \mathrm{H})$, $6.55(\mathrm{~d}, J=19 \mathrm{~Hz}, 2 \mathrm{H}), 6.95(\mathrm{~d}, J=19 \mathrm{~Hz}, 2 \mathrm{H}), 6.97(\mathrm{~d}, J=$ $19 \mathrm{~Hz}, 2 \mathrm{H}), 7.23-7.60(\mathrm{~m}, 18 \mathrm{H}) .{ }^{13} \mathrm{C} \mathrm{NMR}\left(75 \mathrm{MHz}, \mathrm{CDCl}_{3}\right)$ : $\delta=-2.5,126.5,126.9,127.0,127.4,127.6,128.1,128.5,137.4$, 138.3, 140.3, 144.3, 145.0. IR (KBr): $v=3030,2989,2985$, $2899,1912,1604,1574,1448,1401,1335,1250,1198,989,837$, 793, 733. MS m/z 526. Anal. Calcd for $\mathrm{C}_{36} \mathrm{H}_{38} \mathrm{Si}_{2}$ : C, 82.07; H, 7.27. Found: C, $82.35 ; \mathrm{H}, 7.40$.

2,5-Bis \{2,4-(2-dimethyl(2-styryl)silanylvinyl)phenylvinyl -1,4-dibutoxybenzene (4b). Under $\mathrm{N}_{2}$, a mixture of phenylacetylene (7) $(0.102 \mathrm{~g}, 1.0 \mathrm{mmol}), 6 \mathbf{b}(0.30 \mathrm{~g}, 0.5 \mathrm{mmol})$, and $\mathrm{RhCl}\left(\mathrm{PPh}_{3}\right)_{3}(2.3 \mathrm{mg}, 0.5 \mathrm{~mol} \%)$ in THF $(5 \mathrm{~mL})$ was refluxed for $4 \mathrm{~h}$. Removal of the solvent and chromatographic separation on silica gel (hexane) afforded $\mathbf{4 b}(0.34 \mathrm{~g}, 85 \%) ; \mathrm{mp}$ 167-168 ${ }^{\circ} \mathrm{C} .{ }^{1} \mathrm{H}$ NMR $\left(300 \mathrm{MHz}, \mathrm{CDCl}_{3}\right): \delta=0.31(\mathrm{~s}, 12 \mathrm{H})$, $1.01(\mathrm{t}, J=7.4 \mathrm{~Hz}, 6 \mathrm{H}), 1.53-1.61(\mathrm{~m}, 4 \mathrm{H}), 1.80-1.90(\mathrm{~m}, 4$ $\mathrm{H}), 4.05(\mathrm{t}, J=6.3 \mathrm{~Hz}, 4 \mathrm{H}), 6.52(\mathrm{~d}, J=19.1 \mathrm{~Hz}, 4 \mathrm{H}), 6.94$ $(\mathrm{d}, J=19.1 \mathrm{~Hz}, 4 \mathrm{H}), 7.00-7.60(\mathrm{~m}, 24 \mathrm{H}) .{ }^{13} \mathrm{C} \mathrm{NMR}(75 \mathrm{MHz}$, $\left.\mathrm{CDCl}_{3}\right): \delta=-2.5,13.9,19.5,31.6,69.2,110.5,114.2,123.5$, 126.5, 126.7, 126.8, 127.1, 127.4, 128.1, 128.4, 128.5, 137.4, 137.8, 138.3, 144.5, 144.9, 151.1. HRMS: calcd for $\mathrm{C}_{54} \mathrm{H}_{62} \mathrm{Si}_{2} \mathrm{O}_{2}$, 798.4288; found, 798.4285. Anal. Calcd for $\mathrm{C}_{54} \mathrm{H}_{62} \mathrm{Si}_{2} \mathrm{O}_{2}$ : C, 81.15; H, 7.82. Found: C, 80.96; H, 7.87.

1,4-Bis \{[3-phenyl-5-(4-trimethylsilylethynylphenyl)furyl]-2-yl \}benzene (10). Under argon atmosphere, a $2.5 \mathrm{M}$ 
$n$-BuLi in hexane solution $(4.1 \mathrm{~mL}, 10.2 \mathrm{mmol})$ was introduced dropwisely to a THF $(20 \mathrm{~mL})$ solution of propargylic dithioacetal $9(3.22 \mathrm{~g}, 8.5 \mathrm{mmol})$ at $-78{ }^{\circ} \mathrm{C}$, and the mixture was stirred for $50 \mathrm{~min}$. To this mixture was added slowly a THF $(10 \mathrm{~mL})$ solution of terephthaldicarboxaldehyde $(0.52 \mathrm{~g}, 3.9$ mmol) at $-78{ }^{\circ} \mathrm{C}$. The reaction mixture was stirred for $1 \mathrm{~h}$ at $-78{ }^{\circ} \mathrm{C}$, and gradually warmed to room temperature. After further stirring for $1 \mathrm{~h}$ at room temperature, TFA $(1.59 \mathrm{~mL}$, $14.8 \mathrm{mmol}$ ) was added and the mixture was stirred at room temperature overnight. The reaction mixture was quenched with saturated $\mathrm{NH}_{4} \mathrm{Cl}(30 \mathrm{~mL})$, and the organic layer was separated. The aqueous layer was extracted with $\mathrm{Et}_{2} \mathrm{O}(40 \mathrm{~mL}$ $\times 2)$. The combined organic layer was washed with saturated $\mathrm{NaHCO}_{3}(40 \mathrm{~mL} \times 2)$, dried $\left(\mathrm{MgSO}_{4}\right)$, filtered, and evaporated in vacuo. The resulting residue was purified by flash column chromatography (silica gel, $\mathrm{CH}_{2} \mathrm{Cl}_{2}$ /hexane 1:4) to afford the desired 10 as a pale yellow solid (1.52 g, 55\%): mp 184-185 ${ }^{\circ} \mathrm{C} .{ }^{1} \mathrm{H}$ NMR $\left(500 \mathrm{MHz}, \mathrm{CDCl}_{3}\right): \delta=0.27(\mathrm{~s}, 18 \mathrm{H}), 6.83$ (s. 2 $\mathrm{H}), 7.3-7.5(\mathrm{~m}, 10 \mathrm{H}), 7.53(\mathrm{~d}, J=8.3 \mathrm{~Hz}, 4 \mathrm{H}), 7.54,(\mathrm{~s}, 4 \mathrm{H})$, $7.68(\mathrm{~d}, J=8.3 \mathrm{~Hz}, 4 \mathrm{H}) ;{ }^{13} \mathrm{C} \mathrm{NMR}\left(100 \mathrm{MHz}, \mathrm{CDCl}_{3}\right): \delta=$ $0.0,95.3,105.1,110.8,122.0,123.4,125.3,125.9,127.5,128.8$, $129.8,130.2,132.4,134.0,148.0,151.9$. IR (KBr): $v=2966$, 2157, 1673, 1606, 1493, 1251, 929, 865, 842, 764, 698. HRMS: calcd for $\mathrm{C}_{48} \mathrm{H}_{42} \mathrm{O}_{2} \mathrm{Si}_{2}, 706.2723$; found, 707.2736. Anal. Calcd: C, 81.54; H, 5.99. Found: C, 81.18; H, 5.74.

1,4-Bis $\{[3-p h e n y l-5-(4-e t h y n y l p h e n y l) f u r y l]-2-y l\} b e n-$ zene (5d). To a solution of $10(0.42 \mathrm{~g}, 0.6 \mathrm{mmol})$ in methanol $(100 \mathrm{~mL})$ and THF $(125 \mathrm{~mL})$ was added potassium hydroxide $(0.38 \mathrm{~g}, 6 \mathrm{mmol})$. The mixture was stirred at room temperature for $1 \mathrm{~h}$. After removal of the solvent, the product was extracted with chloroform then purified by flash chromatography to give 5d $(0.31 \mathrm{~g}, 92 \%)$ : $\mathrm{mp} 342{ }^{\circ} \mathrm{C}$ (dec). ${ }^{1} \mathrm{H}$ NMR $(500 \mathrm{MHz}$, $\left.\mathrm{CDCl}_{3}\right): \delta=3.14(\mathrm{~s}, 2 \mathrm{H}), 6.84(\mathrm{~s} .2 \mathrm{H}), 7.3-7.5(\mathrm{~m}, 10 \mathrm{H})$, $7.53(\mathrm{~d}, J=8.3 \mathrm{~Hz}, 4 \mathrm{H}), 7.55,(\mathrm{~s}, 4 \mathrm{H}), 7.70(\mathrm{~d}, J=8.3 \mathrm{~Hz}, 4$ H). ${ }^{13} \mathrm{C} \mathrm{NMR}\left(100 \mathrm{MHz}, \mathrm{CDCl}_{3}\right): \delta=78.1,83.7,110.9,120.9$, $123.5,125.3,125.9,127.6,128.7,128.8,129.8,130.6,132.6$, 134.0, 148.0, 151.8. IR (KBr): $v=3293,3059,2926,2110,1625$, 1493, 1392, 1246, 1018, 840, 765, 697. HRMS: calcd for $\mathrm{C}_{42} \mathrm{H}_{26} \mathrm{O}_{2}, 562.1933$; found, 562.1932. Anal. Calcd: C, 89.66; $\mathrm{H}, 4.66$. Found: $\mathrm{C}, 89.39 ; \mathrm{H}, 4.48$.

1,4-Bis \{[3-phenyl-5-(4-[2-(dimethylstyrylsilanyl)-vinyl]phenyl)furyl]-2-yl \}benzene (4d). Under $\mathrm{N}_{2}$, a mixture of 8 $(0.107 \mathrm{~g}, 0.66 \mathrm{mmol}), 5 \mathbf{d}(0.187 \mathrm{~g}, 0.33 \mathrm{mmol})$, and $\mathrm{RhCl}\left(\mathrm{PPh}_{3}\right)_{3}$ (1.5 mg, $0.5 \mathrm{~mol} \%$ ) in $\mathrm{CHCl}_{3}(3 \mathrm{~mL})$ was refluxed for $6 \mathrm{~h}$. Removal of the solvent and chromatographic separation on silica gel $\left(\mathrm{CH}_{2} \mathrm{Cl}_{2}\right)$ to afford a yellow solid, $4 \mathrm{~d}(0.17 \mathrm{~g}, 58 \%)$ : mp 201-203 ${ }^{\circ} \mathrm{C} .{ }^{1} \mathrm{H}$ NMR $\left(400 \mathrm{MHz} \mathrm{CDCl}_{3}\right): \delta=0.34$ (s, 12 $\mathrm{H}), 6.54(\mathrm{~d}, J=19.1 \mathrm{~Hz}, 2 \mathrm{H}), 6.57(\mathrm{~d}, J=19.1 \mathrm{~Hz}, 2 \mathrm{H}), 6.82$, $(\mathrm{s}, 2 \mathrm{H}), 6.98(\mathrm{~d}, J=19.1 \mathrm{~Hz}, 4 \mathrm{H}), 7.3-7.55(\mathrm{~m}, 24 \mathrm{H}), 7.56$ $(\mathrm{s}, 4 \mathrm{H}), 7.73(\mathrm{~d}, J=8.4 \mathrm{~Hz}, 4 \mathrm{H}) .{ }^{13} \mathrm{C}$ NMR $(100 \mathrm{MHz}$, $\left.\mathrm{CDCl}_{3}\right): \delta=-2.5,109.3,110.1,123.9,125.2,125.8,126.5$, $126.9,127.3,127.5,127.6,128.1,128.6,128.8,130.0,134.2$, $137.4,138.2,138.3,144.3,145.0,147.7,152.5$. IR (KBr): $v=$ 2960, 1680, 1604, 1507, 1408, 1254, 1051, 989, 843, 798, 765, 699. HRMS: calcd for $\mathrm{C}_{62} \mathrm{H}_{54} \mathrm{O}_{2} \mathrm{Si}_{2}, 886.3662$; found, 886.3661. Anal. Calcd: C, 83.93; H, 6.13. Found: C, 83.55; H, 6.44.

Polymer 3a. A mixture of $\mathbf{6 a}(48 \mathrm{mg}, 0.15 \mathrm{mmol})$, 5a (30 $\mathrm{mg}, 0.15 \mathrm{mmol})$, and $\mathrm{RhCl}\left(\mathrm{PPh}_{3}\right)_{3}(4.6 \mathrm{mg}, 0.005 \mathrm{mmol})$ in $\mathrm{THF}$ $(2.5 \mathrm{~mL})$ was refluxed under $\mathrm{N}_{2}$ for $4 \mathrm{~h}$. Methanol was added. The precipitate was collected and redissolved in THF and then precipitated again with methanol. The product was collected by filtration and washed with methanol to give $\mathbf{3 a}(67 \mathrm{mg}$, 86\%). ${ }^{1} \mathrm{H}$ NMR $\left(200 \mathrm{MHz}, \mathrm{CDCl}_{3}\right): \delta=0.33(\mathrm{br} \mathrm{s}, 6 \mathrm{H}), 6.56$ $(\mathrm{d}, J=19 \mathrm{~Hz}, 2 \mathrm{H}), 6.98(\mathrm{~d}, J=19 \mathrm{~Hz}, 2 \mathrm{H}), 7.3-7.6(\mathrm{~m}, 8 \mathrm{H})$. IR $(\mathrm{KBr}): v=3032,2959,1646,1604,1496,1402,1252,1050$, 988, 837, 796, 645. Anal. Calcd for $\mathrm{C}_{18} \mathrm{H}_{18}$ Si: C, 82.38. H, 6.91. Found: C, 81.51; H, 6.03.

\begin{tabular}{cclccc}
$\mathrm{RhCl}\left(\mathrm{PPh}_{3}\right)_{3}$ & $\begin{array}{c}\text { time } \\
\left(M \times 10^{-3}\right)\end{array}$ & $\begin{array}{c}\text { temp } \\
(\mathrm{h})\end{array}$ & \multicolumn{1}{c}{$\begin{array}{c}\% \\
\text { yield }\end{array}$} & $M_{\mathrm{n}}$ & $\mathrm{DPI}$ \\
2.0 & 6 & 40 & 75 & 5700 & 2.8 \\
2.0 & 4 & refluxing THF & 86 & 17800 & 3.2
\end{tabular}

Polymer 3b. To a solution of $\mathbf{6 b}(0.30 \mathrm{~g}, 0.5 \mathrm{mmol})$ and $\mathbf{5 b}$ $(0.063 \mathrm{~g}, 0.5 \mathrm{mmol})$ in THF $(2.5 \mathrm{~mL})$ was added $\mathrm{Rh}\left(\mathrm{PPh}_{3}\right)_{3} \mathrm{Cl}$
( $2.3 \mathrm{mg}, 0.5 \mathrm{~mol} \%$ ) under $\mathrm{N}_{2}$. The mixture was refluxed for 4 h. Using the same purification procedure as described above, 3b was obtained $(0.29 \mathrm{~g}, 81 \%) ; M_{\mathrm{n}}=6600, \mathrm{PDI}=2.32$. IR $(\mathrm{KBr}): v=3043,2955,2869,1597,1507,1418,1247,1197$, $1063,1025,839,732 \mathrm{~cm}^{-1} .{ }^{1} \mathrm{H}$ NMR $\left(300 \mathrm{MHz}, \mathrm{CDCl}_{3}\right): \delta=\delta$ $0.31(\mathrm{~s}, 12 \mathrm{H}), 0.98-1.03(\mathrm{~m}, 6 \mathrm{H}), 1.54(\mathrm{~m}, 4 \mathrm{H}), 1.85(\mathrm{~m}, 4$ $\mathrm{H}), 4.04(\mathrm{~m}, 4 \mathrm{H}), 6.51(\mathrm{~d}, J=19.2 \mathrm{~Hz}, 2 \mathrm{H}), 6.93(\mathrm{~d}, J=19.4$ $\mathrm{Hz}, 2 \mathrm{H}), 7.07-7.13(\mathrm{~m}, 4 \mathrm{H}), 7.41-7.46(\mathrm{~m}, 18 \mathrm{H})$. Anal. Calcd for $\mathrm{C}_{48} \mathrm{H}_{56} \mathrm{O}_{2} \mathrm{Si}_{2}$ : C, 79.95; H, 7.83. Found: C, 79.38; H, 7.52.

Polymer 3c. To a solution of $6 \mathbf{c}(123 \mathrm{mg}, 0.5 \mathrm{mmol})$ and $5 \mathbf{c}$ (135 mg, $0.5 \mathrm{mmol})$ in THF $(2.5 \mathrm{~mL})$ was added $\mathrm{Rh}\left(\mathrm{PPh}_{3}\right)_{3} \mathrm{Cl}$ (2.3 mg, $0.5 \mathrm{~mol} \%$ ) under $\mathrm{N}_{2}$. Using the same purification procedure as described above, $3 \mathbf{c}$ was obtained (210 $\mathrm{mg}, 82 \%)$; $M_{\mathrm{n}}=15600, \mathrm{PDI}=2.97 . \mathrm{IR}(\mathrm{KBr}): v=2949,1608,1541,1489$, 1247, 1180, 1014, 984, 836, 727, 668. ${ }^{1} \mathrm{H}$ NMR $(400 \mathrm{MHz}$, $\left.\mathrm{CDCl}_{3}\right): \delta=0.36(\mathrm{br} \mathrm{s}, 12 \mathrm{H}), 6.55(\mathrm{~d}, 4 \mathrm{H}), 6.70(\mathrm{~d}, 4 \mathrm{H}), 6.8-$ $7.1(\mathrm{~m}, 4 \mathrm{H}), 7.45(\mathrm{~s}, 4 \mathrm{H}), 7.61(\mathrm{~s}, 4 \mathrm{H}), 8.11$ (s, $4 \mathrm{H})$. Anal. Calcd: C, 74.37; H, 6.24. Found: C, 75.45; H, 7.22.

Polymer 3d. To a solution of $\mathbf{6 c}(0.1 \mathrm{~g}, 0.4 \mathrm{mmol})$ and $\mathbf{5 d}$ $(0.26 \mathrm{~g}, 0.4 \mathrm{mmol})$ in THF $(2.5 \mathrm{~mL})$ was added $\mathrm{Rh}\left(\mathrm{PPh}_{3}\right)_{3} \mathrm{Cl}$ (1.9 mg, $0.5 \mathrm{~mol} \%$ ) under $\mathrm{N}_{2}$. The mixture was refluxed for 4 h. Using the same purification procedure as described above, 3d was obtained $(0.25 \mathrm{~g}, 71 \%) ; M_{\mathrm{n}}=13200$, PDI $=2.75 .{ }^{1} \mathrm{H}$ $\operatorname{NMR}\left(400 \mathrm{MHz}, \mathrm{CDCl}_{3}\right): \delta=0.33(\mathrm{br} \mathrm{s}, 12 \mathrm{H}), 6.4-6.6(\mathrm{~m}, 4$ $\mathrm{H}), 6.8(\mathrm{~s}, 2 \mathrm{H}), 6.9-7.1(\mathrm{~m}, 4 \mathrm{H}), 7.3-7.6(\mathrm{~m}, 22 \mathrm{H}), 7.6-7.8$ $(\mathrm{m}, 4 \mathrm{H})$. IR $(\mathrm{KBr}): v=2961,1673,1604,1447,1408,1255$, 1048, 990, 843. Anal. Calcd: C, 83.12; H, 5.98. Found: C, $84.21 ; \mathrm{H}, 6.67$.

Acknowledgment. We thank the National Science Council and the Ministry of Education of the Republic of China for support. Y.J.C. thanks the Yen-Chuang Foundation for a best thesis award (2004) and the Chinese Chemical Society, Taipei, Republic of China, for outstanding graduate research (2004).

\section{References and Notes}

(1) (a) Burn, P. L.; Holmes, A. B.; Kraft, A.; Bradley, D. D. C. Brown, A. R.; Friend, R. H.; Gymer, R. W. Nature (London) 1992, 356, 47. (b) Yang, Z.; Sokolik, I.; Karasz, F. E. Macromolecules 1993, 26, 1188. (c) Kim, D. J.; Kim, S. H.; Lee, J. H.; Kang, S. J.; Kim, H. K.; Zyung, T.; Cho, I.; Choi, S. K. Mol. Cryst. Liq. Cryst. 1996, 280, 391. (d) Brouwer, H. J.; Krasnikov, V. V.; Hilberer, A.; Hadziioannou, G. Adv. Mater. 1996, 8, 935 and references therein.

(2) (a) Hu, S. S.; Weber, W. P. Polym. Bull. (Berlin) 1989, 21, 133. (b) Corriu, R. J. P.; Guerin, C.; Henner, B.; Kuhlmann, T.; Jean, A.; Garnier, F.; Yassar, A. Chem. Mater. 1990, 2, 351. (c) Ohshita, J.; Kanaya, D.; Ishikawa, M.; Koike, T.; Yamanaka, T. Macromolecules 1991, 24, 2106. (d) Wu, H. J.; Interrante, L. V. Macromolecules 1992, 25, 1840. (e) Pang, Y.; Ijadi-Maghsoodi, S.; Barton, T. J. Macromolecules 1993 26, 5671. (f) Malliaras, G. G.; Herrema, J. K.; Wildeman, J.; Wieringa, R. H.; Gill, R. E.; Lampoura, S. S.; Hadziioannou, G. Adv. Mater. 1993, 5, 721. (g) Yuan, C.-H.; West, R. Appl. Organomet. Chem. 1994, 8, 423. (h) Najchrzak, M.; Itami, Y.; Marciniec, B.; Pawluc, P. Macromol. Rapid Commun. 2001，22，202. (i) Kim, H. K.; Ryu, M.-K.; Lee, S.-M. Macromolecules 1997, 30, 1236. (j) Miao, Y.-J.; Bazan, G. C. Macromolecules 1997, 30, 7414. (k) Kim, H. K.; Ryu, M. K.; Kim, K. D.; Lee, S. M.; Cho, S. W.; Park, J. W. Macromolecules 1998, 31, 1114. (1) Jung, S. H.; Kim, H. K.; Kim, S. H.; Kim, Y. H.; Jeoung, S. C.; Kim, D. Macromolecules 2000, 33, 9277.

(3) (a) Son, D. Y.; Bucca, D.; Keller, T. M. Tetrahedron Lett. 1996 , 37, 1579. (b) Mori, A.; Takahisa, E.; Kajiro, H.; Nishihara, Y.; Hiyama, T. Macromolecules 2000, 33, 1115. (c) Kunai, A.; Toyoda, E.; Nagamoto, I.; Horio, T.; Ishikawa, M. Organometallics 1996, 15, 75. (d) Li, H.; West, R. Macromolecules 1998, 31, 2866. (e) Oshita, J.; Takada, A.; Kunai, A.; Komaguchi, K.; Shiotani, M.; Adachi, A.; Sakamaki, K.; Okita, K.; Harima, Y.; Konugi, Y.; Yamashita, K.; Ishikawa, M. Organometallics 2000, 19, 4492. (f) Fang, M.-C.; Watanabe, A.; Matsuda, M. Macromolecules 1996, 29, 6807.

(4) (a) Gao, Z.; Lee, C. S.; Bello, I.; Chen, R.-M.; Luh, T.-Y.; Shi, J.; Tang, C. W. Appl. Phys. Lett. 1999, 74, 865. (b) Chen, R.-M.; Deng, Z.; Lee, S. T.; Luh, T.-Y. In Semiconductive 
Polymers, ACS Symposium Series; Hsieh, B. R., Galvin, M., Wei, Y., Eds.; American Chemical Society: Washington, DC, 1999; Chapter 23, pp 374-383. (c) Luh, T.-Y.; Chen, R.-M.; Hwu, T.-Y.; Basu, S.; Shiau, C.-W.; Lin, W.-Y.; Jin, B.-Y.; Hsu, C. C. Pure Appl. Chem. 2001, 73, 243.

(5) Chen, R.-M.; Luh, T.-Y. Tetrahedron 1998, 54, 1197.

(6) (a) Cheng, Y.-J.; Hwu, T.-Y.; Hsu, J.-H.; Luh, T.-Y. Chem Commum 2002, 1978. (b) Cheng, Y.-J.; Luh, T.-Y. Chem.Eur. J. 2004, 10, 5361.

(7) (a) Chen, R.-M.; Chien, K.-M.; Wong, K.-T.; Jin, B.-Y.; Luh, T.-Y.; Hsu, J.-H.; Fann, W. J. Am. Chem. Soc. 1997, 119 11321. (b) Hwu, T.-Y.; Basu, S.; Chen, R.-M.; Cheng, Y.-J.; Hsu, J.-H.; Fann, W.; Luh, T.-Y. J. Polym. Sci., Part A: Poly. Chem. 2003, 2218.

(8) Cheng, Y.-J.; Liang, H.; Luh, T.-Y. Macromolecules 2003, 36, 5912.

(9) (a) Hu, D. H.; Yu, J.; Wong, K.; Bagchi, B.; Rossky, P. J.; Barbara, P. F.; Nature 2000, 405, 1030 and references therein. (b) Grosberg, A. Y.; Kuznetsov, D. V. Macromolecules 1992, 25, 1970. (c) Ivanov, V. A.; Paul, W.; Binder, K. J. Chem. Phys. 1998, 109, 5659. (d) Noguchi, H.; Yoshikawa, K. J. Chem. Phys. 1998, 109, 5070. (e) Kuznetsov, Y. A.; Timoshenko, E. G. J. Chem. Phys. 1999, 111, 3744. (f) Becker, H.; Spreitzer, H.; Kreuder, W.; Kluge, E.; Schenk, H.; Parker, I.; Cao, Y. Adv. Mater. 2000, 12, 42.

(10) Wong, K. F.; Skaf, M. S.; Yang, C. Y.; Rossky, P. J.; Bagchi, B.; Hu, D. H.; Yu, J.; Barbara, P. F. J. Phys. Chem. B 2001, 105,6103 .
(11) (a) For a recent review, see: Brédas, J. L.; Cornil, J.; Beljonne, D.; dos Santos, D. A.; Shuai, Z. G. Acc. Chem. Res. 1999, 32 267 and references therein. (b) Cornil, J.; dos Santos, D. A.; Crispin, A. X.; Silbey, R.; Brédas, J. L. J. Am. Chem. Soc. 1998, 120, 1289. (c) Siddiqui, S.; Spano, F. C. Chem. Phys. Lett. 1999, 308, 99. (d) Spano, F. C.; Siddiqui, S. Chem. Phys. Lett. 1999, 314, 481. (e) Cornil, J.; Beljonne, D.; Calbert, J. P.; Brédas, J. L. Adv. Mater. 2001, 13, 1053.

(12) (a) Miao, Y.-J.; Herkstroeter, W. G.; Sun, B. J.; Wong-Foy, A. G.; Bazan, G. C. J. Am. Chem. Soc. 1995, 117, 11407. (b) Bazan, G. C.; Oldham, W. J.; Lachicotte, R. J.; Tretiak, S.; Chernyak, V.; Mukamel, S. J. Am. Chem. Soc. 1998, 120, 9188. (c) Wang, S. J.; Bazan, G. C.; Tretiak, S.; Mukamel, S. J. Am. Chem. Soc. 2000, 122, 1289. (d) Gaylord, B. S.; Wang, S.; Heeger, A. J.; Bazan, G. C. J. Am. Chem. Soc. 2001, 123, 6417. (e) For a recent review, see: Bartholomew, G. P.; Bazan, G. C. Acc. Chem. Res. 2001, 34, 30.

(13) The emission profiles for copolymer $\mathbf{1}$ and related polymers were essentially concentration independent $\left(10^{-2}-10^{-4} \mathrm{~g} / \mathrm{L}\right)$. Interchain chromophore-chromophore interaction, if any, could be negligibly weak. At higher concentration (e.g. 1 g/L), such interchain aggregation may occur (cf. refs 7 and. 8).

(14) Lee, C.-F.; Yang, L.-M.; Hwu, T.-Y.; Feng, A.-S.; Tseng, J.C.; Luh, T.-Y. J. Am. Chem. Soc. 2000, 122, 4992.

MA047713C 